\title{
Aspects of Violence in the Early Arab-Byzantine Wars, Some Remarks on Military Necessity and Source Ideology
}

\author{
Abdelaziz Ramadan \\ King Khalid University, Saudi Arabia \\ aramadan@kku.edu.sa \\ Abstract: \\ تتعامل النصوص المسيحية الثرقية مع الحروب العربية البيزنطية المبكرة بدوافع \\ أيديولوجية واضحة، فهي غالبًا ما تتسب إلى العرب أعمال عنف مفرطة، ليس ضد أعدائهم \\ المحاربين بل ضد المدنيين وأحبانًا الرهبان. ويزداد اتهام العرب بالعنف حدة في نصوص الكتاب \\ ذوي الخلفية الدينية. وقد اعتمد بعض العلماء على هذه النصوص كدليل على عنف الفتوحات \\ العربية دون مراعاة لتأثير الخلفية الدينية لأولئك الكتاب على رؤيتهم للإسلام كتهديد للمسيحية، \\ ثم لنفوذهم ومناصبهم كرجال دين؛ فراحوا يعبروا عن استيائهم الثنديد من دخول كثثر من شعب \\ كنائسهم إلى الإسلام، واعتبروه عقابًا إلهيًا على خطايا المسيحيين. ويبدو أن بعضهم بالغ في \\ العقاب الدموي والوحشي تمهيداً للمغفرة والانتصار النهائي للمسيحيين الحقيقيين. ويمكن دعم هذا \\ الطرح من خلال مقارنة ما كتبوه مع كتابات رجال دين آخرين غير متعصبين كانت أكثر ميلًا \\ إلى سلمية الفتوحات العربية. \\ من ناحية أخرى، يبدو موقف الكتاب البيزنطيين الأقرب إلى الموقف العربي؛ فهم لا \\ يقصرون العنف على العرب فقط، بل يشيرون إلى عنف متبادل بين الخصمين، العرب \\ والبيزنطيين؛ وهذا يتفق إلى حد كبير مع المصادر العربية. ورغم ندرة الروايات العربية ذات \\ الصلة، فالمتاح منها يثنير إلى هذا العنف المتبادل. ويعد الواقدي مصدرًا فريدًا في إثنارته إلى لى \\ حوادث هذا العنف المتبادل. لكن رغم أنه ذكر عددًا من حوادث العنف التي ارتكبها الجانب \\ العربي، إلا أنه غالبًا ما بررها بالضرورة الاستراتيجية التي تستدعيها الحرب، بل اعتبرها من \\ أعمال البطولة والثجاعة الضرورية لترويع الأعداء.
}

\section{Abstract:}

Eastern Christian texts deal with the early Arab-Byzantine wars with clear ideological motives. They often attribute to the Arabs extreme violence directed not against their warrior enemies but against civilians and sometimes monks. The accusation of Arabs of extreme violence is increasing in the texts of writers with a religious background. Some 
scholars have relied on these texts as an evidence for the violence of the Arab conquests without taking into account the influence of the religious background on those writers who saw Islam as a threat to Christianity, and then on their influence and positions as clerics. Some of them expressed their strong dissatisfaction with the conversion of the people of their churches to Islam and considered this a divine punishment for the moral sins of Christians. Thus, it seems that some of them exaggerated the bloody and brutal punishment in preparation for forgiveness and the final victory of true Christians over Muslims. This approach may be supported by a comparison of what they wrote with other non-fanatic clerics who were more inclined to the pacifism of the Arab conquests.

On the other hand, the position of the Byzantine writers seems closer to the Arab position. They do not limit the violence to the Arabs only, but refer to the violence of the two opponents, the Arabs and the Byzantines. At times, they justified the violence of Arab fighters against rebels or enemy collaborators. This is largely in agreement with Arabic sources, and although related Arabic accounts are scarce, what is available of them indicate a common violence between the two rivals.

Al-Wāqidī is a unique source in his reference to incidents of mutual violence. However, although he mentioned a number of violent incidents perpetrated by the Arab side, he often justified this by the necessity of the strategy required by the wars against the unbelievers He frequently considered it an act of heroism and courage that was necessary to terrify them.

Keywords: Violence, Early Arab-Byzantine Wars, Byzantium, Islamic State, Byzantine-Arab relations.

"It is better to fight thieves than to fight the Romans." Speech attributed to the Muslim jurist Anas b. Mālik (died 179/795), and al-Hajjāj (d. 95/714), the Umayyad ruler of Küfa, used it to justify his harsh policies against rebellions. ${ }^{1}$ The same impression may penetrate the reader who

\footnotetext{
${ }^{1}$ Ibn Farḥūn, Abū Isḥāq Ibrāhīm b. 'Alī al-Ya murī. Durrat al-Ghawwāṣ fì Muhạdarat al-Khawas, ed. M. Abū al-Ajfān \& 'U. al-Batīkh, Beirut: Mu'assasat al-Risāla, 1985, II, 185. This passage, even if correctly attributed to Anas b. Mālik, does not mean his refusal of the Jihād against the Byzantines. Although he was extremely cautious-even doubtful-about the legitimacy of a Muslim offering his duty of Jihād in border warfare led by the Umayyads, presumably because of questions on the legitimacy of their rule, but he approved the jihād. In al-Mudawwanah, his teachings, which was compiled by Saḥūn (d.240/854), there are many passages indicate this approval. He is asked several times: Do you see any harm in fighting the Jihăd against the Byzantines
} 
searches for data on violence in the Arab-Byzantine war. The sources of the two worlds are full of examples of political violence, or extreme violence, against coups, rebellions, and riots ${ }^{2}$, while those of ArabByzantine violence in battlefields become rarer. I think this is an expected matter in sources that mainly concentrated on internal affairs, but this does not mean the complete absence of evidence of violence in the Arab-Byzantine conflict, especially in its early period. ${ }^{3}$

In the seventh century, the Arab conquests of Syria, Palestine, and Egypt led the Arabs and the Byzantines to the road of open military confrontation. The rapid advance of Islam and the easy fall of the eastern provinces caused a great confusion to both the Byzantines and some Christians of Syria and Egypt. The two major Byzantine historians of the eight century, writing from a religious background, resorted to dealing briefly with the events, but they did not openly accuse the Arabs of cruelty and barbarism as some other Eastern Christian literature done.

Theophanes the Confessor refers to the bloody nature of these wars when he describes the battle of Phoinix in 655 by saying: "when the two sides engaged, the Romans were defeated and the sea was dyed with Roman blood". $4 \mathrm{He}$ often refers to the thousands of casualties and prisoners of war on both sides. According to him, in 637/8, the Arabs captured the city of Constantine by sword and killed 300 Byzantines, then took the city of Daras by war and slew many people therein. ${ }^{5}$ In 640/1, they captured Caesarea in Palestine after seven-years' siege and killed 7,000 Byzantines. ${ }^{6}$ They also captured Isauria in 650, killing many men and capturing 5,000 prisoners. $^{7}$

alongside these rulers? He repeatedly says: "There is no harm in doing so", twice justifying his standby mentioning the Byzantine success at Mar'ash (Germanikeia), presumably referring to its destruction by Constantine V in 129/746. Sahnūn, Abū Sa‘īd Saḥnūn b. Sa‘īd b. Habīb al-Tanūkhī, al-Mudawwanah, Cairo: Maṭba'at alSa'ādah, 1323, p3-5.Cf. Mottahedeh, R., \& R. al-Sayyid, "The Idea of the Jihād in Islam before the Crusades", in: A.E. Laiou \& R. Mottahedeh (eds.), The Crusades from the Prospective of Byzantium and the Muslim World, Washington, D.C., 2001, 23-29, es 26.

2 See: Kh. Abou el-Faḍl, Rebellion and Violence in Islamic Law, Cambridge: Cambridge University press, 2006; W. E. Kaegi, Byzantine Military Unrest 471-843: An Interpretation, Amsterdam: Adolf M. Hakkert Publisher, 1981.

${ }^{3}$ E.g. see Tarek M. Muhammad, "Had the Arabs Military Skills or Tactics during their Early Conquests of Bilād al-Shām?", in East and West; Essays on Byzantine and Arab Worlds in the Middle Ages, ed. J. P. Monferrer-Sala, V. Christides, and Th. Papadopoullos, New Jersey: Gorgias press 2009, 71-84.

4 Theophanes the Confessor, Chronographia, Eng. trans. C. Mango and R. Scott, Oxford: Clarendon Press, 1997, 482.

${ }^{5}$ Theophanes, Chronographia, 341.

6 Theophanes, Chronographia, 475.

${ }^{7}$ Theophanes, Chronographia, 479. 
D. J. Constantelos, in his treatment of the Chronographia of Theophanes, appreciates it as a valuable and reliable source for the Arabic conquest of Syria and Palestine, considering that it "emphasized the greed, barbarism and cruelty of the conquerors". ${ }^{8} \mathrm{He}$ deliberately selected all the mentioned references to the attacks of Muslims and the large numbers of Byzantine victims and captives, ${ }^{9}$ ignoring those that refer to thousands of Arab deaths during the same period. ${ }^{10}$ It was reported by Theophanes that in the year 632/3, Theodore the Skellarios met a large number of Arabs at Emesa, and slew them together with their emir. ${ }^{11}$ The Byzantines also killed 30,000 Arabs near Kyzikos in 672/3. ${ }^{12}$ In 699, according to Theophanes, the Byzantines invaded Syria, killed 200,000 Arabs in Samosata, and took many captives. ${ }^{13}$ They also killed 12,000 Arabs near Cilicia in 703. ${ }^{14}$

On the other hand, Theophanes does not ascribe to Arabs deeds of extreme violence. The only example of this sort, which can be found in his Chronographia, does not be against Byzantines but the Armenians. In 84/703-4, Muhammad b. Marwān made an expedition against the Armenians, killed many people, gathered their leaders in one place and burnt them alive. ${ }^{15}$ Even in this event, Theophanes does not leave us without presenting the reason of this cruel action. It is the desire of revenge and punishment as "the Armenian chieftains rebelled against the Saracens and killed those who were in Armenia. Once more they made contact with Apsimaros (the Byzantine Emperor) and brought the Romans into their country". ${ }^{16}$

The Patriarch Nikephoros, who does not give any details, refers to some aspects of violence during the early Arab conquests. According to him, there were many killed Byzantine soldiers and officers at Gabitha (Ajnādīn) in 635. ${ }^{17}$ Also, in 707-8, Emperor Justinian II collected a numerous body of peasants and farmers to relieve the besieged city of

\footnotetext{
${ }^{8}$ Constantelos, D. J., "The Moslem Conquests of the Near East as Revealed in the Greek Sources of the Seventh and the Eighth Centuries", Byzantion XLII (1972), p323-357, es 335 .

${ }^{9}$ Constantelos, "The Moslem Conquests", 338.

${ }^{10}$ Constantelos, in his view, focuses mainly on what he calls "the persecution against the Christian population" that Theophanes attributed to the Umayyads, ignoring that their era dates back to the beginning of the eighth century, that is, more than half a century after the Arab conquest of Syria, Palestine and Egypt.

11 Theophanes, Chronographia, 468.

12 Theophanes, Chronographia, 494.

13 Theophanes, Chronographia, 518.

14 Theophanes, Chronographia, 520.

15 Theophanes, Chronographia, 520.

16 Theophanes, Chronographia, 519-520.

${ }^{17}$ Nikephoros Patriarch of Constantinople, Short History, Eng. trans. C. Mango. Corpus Fontium Hisroriae Byzantinae 13, Washington, D.C., 1990, 69.
} 
Tyana (Ṭowānah). On seeing them unarmed, the Arabs rushed against them putting some to the sword and captured the others. They advanced as far as Chrysopolis, massacred the local inhabitants, and set fire to the ferry boats. ${ }^{18}$ The only example of extreme violence against the Byzantines, which Nikephoros ascribes to the Arabs, is the merciless way by which they killed the General Sergios in Palestine 13/634. He describes it by saying that "The Saracens, having flayed a camel, enclosed him in the hide and sewed it up. As the skin hardened, the man who was left inside also withered and so perished in a painful manner". ${ }^{19}$

Evidence for extreme violence, which attributed to the Arab conquests, can be derived primarily from the Eastern Christian writings. ${ }^{20}$ They often talk about killing many civilians. A record dated 637 indicates that many villages were ruined and a large number of people were killed. $^{21}$ Thomas the priest, the proposed author of a chronicle composed in 640, refers to a battle between the Byzantines and the Arabs in Palestine, most likely Ajnādīn, saying that "the Byzantines fled leaving behind the Patrikios the son of Yrdn (Werdān) whom the Arabs killed. They also killed about 4,000 inhabitants of the poor villages of Palestine, Christian, Jews and Samaritans". ${ }^{22}$ Thomas also records the

\footnotetext{
${ }^{18}$ Nikephoros, Short History, 107.

${ }^{19}$ Nikephoros, Short History, 69. Nikephoros attributes the reason of this sever way of killing to Arabs' desire of revenge, he says: "the charge against him was that he had persuaded Herakleios not to allow the Saracens to trade from the Roman country and send out of the Roman State the $30 \mathrm{lbs}$. of gold which they normally received by way of commercial gain; and for this reason they began to lay waste the Roman land.”. I think that the whole account is fabricated. Theophanes does not refer to this story but only says that Sergios "was first to be killed along with his soldiers, who were 300". Arabic and Syrian sources mention his killing by sword during the battle. Theophanes, Chronicle, 467;

${ }^{20}$ Here, I will try to avoid dealing with Eastern Christians' response to Islam, the problem that has attracted close attention of modern scholarship. For examples see: Constantelos, Moslem Conquests, 323-357; Moorhead, J., "The Monophysite Response to the Arab Invasions", Byzantion LI (1981), 579-591; Brock, S., "Syriac Views of Emergent Islam”, in: Studies on the First Century of Islamic Society, ed. G.H.A. Juynboll, Carbondale and Edwardsville, 1982, 9-21, 199-203. Reprinted in Idem, Syriac Perspectives on Late Antiquity, London, 1984, no. VIII; Reinink, G. J., "Pseudo-Methodius: A Concept of History in Response to the Rise of Islam", in: The Byzantine and Early Islamic Near East, I: Problems in the Literary Source Material, Princeton, 1992, 149-188.

${ }^{21}$ A Record Dated AD 637, trans. A. Palmer, in: The Seven Century in the West-Syrian Chronicles, Liverpool: Liverpool University Press, 1993, p2,3. It also refers to many Byzantine dead in Gabitha.

${ }^{22}$ A Chronicle Composed AD 640, trans. A. Palmer, in: The Seven Century in the WestSyrian Chronicles, Liverpool: Liverpool University Press, 1993, 18-19. Later Syriac chronicles are not empty of such violent deeds which ascribed to the Arab against the civil populations. The chronicle of Zuqnīn, which dated to 775, records that when the Arabs laid siege to Dara and attacked it, a great many people were slain. Also, when they attacked Adavīn in the same year, many people were killed as many as 1200 of
} 
earlier, and seems to be the only, example of violence against monks that the syriac sources attribute to the Arab armies. According to him, when Sa'd b. Abī Waqqās was sent against the Persians, the Arabs on their way climbed the mountain of Mardin and killed many monks there in the monasteries of Qedar and $\mathrm{B}^{\mathrm{e}}$ nōthō, i.e. the eggs. Thomas himself lost his brother, Simon the doorkeeper of Qedar, in this attack. ${ }^{23}$ This event is repeated by the late chronicles of Dionysius of Tel-Mahrē $(818-845)^{24}$ and Michael the Syrian, but the later is the only who justifies this act saying that the Arabs "were told that the monks were Persian spies". ${ }^{25}$

The accusation of Arabs of extreme violence becomes more intense in the eastern sources of a religious background. The Greek sermons of Sophronios, Patriarch of Jerusalem at the time of its conquest, describe the Arabs as "godless foreigners" who threaten with massacres, destruction and their "bloodthirsty" swords. According to him, the Arabs destroyed the corps of fields, burned down towns and churches and attacked monasteries. ${ }^{26}$

In the second half of seventh century, the Syriac Apocalypse of Pseudo- Methodios, dating from 691-2, ascribes to the Arabs all sorts of cruelty and barbarism. It portrays them as "barbarian tyrants" and "children of desolation". According to it, "the people will be persecuted, wild animals and cattle will die, the forest tree will be cut down, the most beautiful mountains plants will be destroyed, and prosperous cities will be laid waste". The Arabs also "will make a sacrifice of those who minister in the sanctuary, and they even will sleep with their wives and with captive women inside the sanctuary. They will tether their cattle to the sarcophagi of martyrs and to the graves of holy men. They are insolent murders, destructives shedders of blood; they are a "furnace of testing' for all Christians". ${ }^{27}$

the Armenians. 'The chronicle of Zuqnīn, AD 775', A. Palmer, in: The Seven Century in the West-Syrian Chronicles, Liverpool: Liverpool University Press, 1993, 57.

${ }^{23}$ A Chronicle Composed AD 640, 19.

24 The Secular History of Dionysius of Tel-Mahrē, trans. A. Palmer, in: The Seven Century in the West-Syrian Chronicles, Liverpool: Liverpool University Press, 1993, 150.

${ }^{25}$ The General Chronicle of Michael the Syrian, Patriarch of Antioch, Arabic trans. G.S. Shamoun, Damascus, 1996, II, 334.

${ }^{26}$ Constantelos, Moslem Conquests, 329-330.

27 'An Extract from the Apocalypse of Pesudo-Methodios', trans. S. Brock, in: The Seven Century in the West-Syrian Chronicles, Liverpool: Liverpool University Press, 1993, 232. See also another English translation in Martinez, F.J., Eastern Christian Apocalyptic in the Early Muslim Period: Pseudo-Methodius and Pseudo-Athanasius, Ph.D. dissertation: The Catholic University of America, 1985, 144-145. A contemporary Edessene apocalyptic fragment, which is also dated to 691-2, repeats the same accusations. See: 'The Edessene Apocalyptic Fragment', trans. S. Brock, in: 
Some modern scholars, discussing these texts, rely on them as evidence for that "the Arab conquests must have been very violent" 28 . It should be borne in mind that these texts were written under critical conditions and for special reasons. It is natural that their writers, who are from a religious background, see Islam as a great danger to Christianity and must feel that their religion, and therefore their positions in the priestly clergy, will lose their influence. ${ }^{29}$ Pseudo- Methodios, generally believed to be a bishop ${ }^{30}$, expressed strong dissatisfaction with the large numbers of his co-religionists who "Without violence, torments or blows, will deny Christ, and make themselves like pagans". ${ }^{31}$ Sophronios, who had just been elected to the patriarchal throne of Jerusalem (in the year 634), logically hated the Arab conquest of Jerusalem, the event that deprived him of the opportunity to exercise his supreme religious authority on a city that was before an absolute Christian one.

Moreover, the real problem for these writers is how they can explain the rapid advance of Islam. While some Eastern Christians may have tended to explain this by looking at Islam as a true religion, clergymen thought it necessary to find another appropriate explanation. They resorted to the ideology of "divine punishment" for the moral sins of Christians ${ }^{32}$, and believed that the more exaggerated the severity of

The Seven Century in the West-Syrian Chronicles, Liverpool: Liverpool University Press, 1993, 244-245.

${ }^{28}$ Constantelos, Moslem Conquests, 329.

29 This feeling is entirely confirmed by Pesudo-Methodios who says "Honour will be taken away from priests, the Divine Office and the Living Sacrifice will come to an end in the Church; priests will be like the common people at that time". An Extract, 236; Martinez, F.J., Eastern Christian Apocalyptic, 147.

${ }^{30}$ An Extract, 222-226; Martinez, F.J., Eastern Christian Apocalyptic, 1-8, 25-28.

${ }^{31}$ I cite here the translation of Martinez, Eastern Christian Apocalyptic, 145-146. S. Brock translates the passage as fellow: "Many people were members of the Church will deny the true faith of the Christians... without being subjected to any compulsion, or lashings or blows, they will deny Christ, putting themselves on a par with the unbelievers". An Extract, 235; I find this passage is entirely contradicted with extreme violence that Pesudo-Methodios tries to ascribe to the Arab conquests. G. R. Reinink is entirely right when concludes that "The main problem for Ps.-Methodios is in fact the danger of voluntary apostasy by members of his own Church". Reinink, 'PseudoMethodius', 159.

${ }^{32}$ Pseudo-Methodius attributes the reason of Arabs' victories to that "It is not because God love them that He allows them to enter into the kingdom of the Christians, but because of the iniquity and the sin that is being wrought by the Christians". An Extract, 231; Martinez, F. J., Eastern Christian Apocalyptic, p144-145. Also, Sophronios confirms that the joy of a visit to Bethlehem had denied them due to the sins of Christians. Fear of Saracens inflicted upon them sorrow and misery. He likens the state of the Christians to that of Adam expelled from Paradise. Nevertheless, he stresses that repentance and reconciliation with the God could dispel the Saracens menace and eventually lead the Christians to Bethlehem. Constantelos, 'Moslem Conquests', 239. 
this punishment, the more possible and imminent God's forgiveness was. Thus, it appears that Sophronios and Pseudo-Methodios have deliberately exaggerated their description of the cruel divine punishment as a prelude to obtaining forgiveness and achieving the ultimate victory of true Christians over Muslims. ${ }^{33}$

Among the Syriac chronicles, the History of the Jacobite Patriarch Dionysius of Tel-Mahrē (818-845) presents very different attitudes. The Arabs here are tolerant and merciful. They had to fight only when they encounter stiff resistance from the Syrian cities. However, when these cities surrender, always when they are in desperate of Byzantine help, the Arabs give their populations written contracts guaranteeing them the security of their lives, possessions, churches and laws. ${ }^{34}$ In the case of Damascus, the mediator of such agreement was the Deacon John the Damascene who "was loved and well-known among the Arabs. ${ }^{35}$ Also, Dionysius seems to justify the philosophy of the tribute, i.e. al-jizyah, which these cities had to pay. Before the battle of al-Yarmūk, the commander-in-chief of the Arabs, Abū 'Ubayda, ordered the return of the tribute which had been taken from the Emesenes and Damascenes, saying that "If we return victorious, we shall take it back. But if we are defeated and prove powerless to save you from the Byzantines, here is your tribute: keep it! We, for our part, shall be absolved of the oaths which we have sworn to you". ${ }^{36}$

\footnotetext{
${ }^{33}$ Reinink is entirely right when observes that "The role of the 'sons of Ishmael' is confined to that of a temporary 'chastisement', a scourge in the hand of God to destroy the 'fatlings of the Greeks', to punish the Christians because of their sins (especially sexual ones), and to separate the true believers from the unbelievers, viz. apostates". Reinink, 'Pseudo-Methodius', 159.

34 As for the cases of Damascus and Emesa which surrendered in 13, Aleppo, Qēnneshrīn and "the rest of that region". "The Secular History of Dionysius of TelMahre', 154-155. Dionysius here seems to be harmonized with the Arabic sources. According to them, the Arabs took many cities by sword and after the surrender of their populations whom were granted such covenant. These cities are Damascus and Emesa in 13; B'albaak, Hemṣ, Lāzqyah, Qennesrīn and Aleppo in 15; Antioch in 16. Al-Ṭabarī (Muḥammad Abū al-Fạ̣l b. Garīr), Tarīkh al-Rusul wal Mulūk, ed. M.A.Ibrahīm, Cairo: Dār al-Ma'arif, 1967, III, 418,439,599-600; Ibn al-Athīr (Abū alḤasan 'Alī b. 'Abd al-Waḥid al-Šaybanī), Al-Kāmil fì al-Tarīkh, Beirut: Dār al-Kutub al-'Ilmiā, 1987, II, 279,339,340,341. Nevertheless, in the case of Antioch, Dionysius records that Mu'āwiya b. Abī Sufyān "took Antioch by siege and plundered the villages around, leading the people away as slaves". Also, he states that Mu'āwiya besieged Caesarea with vigorous assaults, taking captives and laying it waste. All those in the city, including 7000 Byzantines sent there to protect it, were put to death. 'The Secular History of Dionysius of Tel-Mahrē', 163, 165-166. Arabic sources confirm what happened to Caesarea $15 \mathrm{H}$. or $19-20 \mathrm{H}$., recording 80.000 of killings. AlTabarī, Tarīkh, III, 604; Ibn al-Athīr, al-Kāmil, II, 344.

35 'The Secular History of Dionysius of Tel-Mahrē', 155.

36 'The Secular History of Dionysius of Tel-Maḥrē', 156-7.
} 
The few examples of violence that Dionysius ascribes to the Arabs were exclusively directed against the Byzantines and in the Mesopotamian cities, which they refuse to surrender. ${ }^{37}$ For Syrians, this violence is often perpetrated by the Byzantines rather than by the Arabs'. At the Ave of al-Yarmūk battle, "As the Romans marched towards the Arab camp every city and village on their way, which had surrendered to the Arabs, shouted threats at them. As for the crimes the Romans committed on their passage, they are unspeakable, and their unseemliness ought not even to be brought to mind". ${ }^{38}$ After the battle, "The Damascenes greeted them (the Arab armies) outside the city and welcomed them joyfully in, and all treaties and assurances were reaffirmed". ${ }^{39}$ Here the Jacobite Patriarch, who selected and combined material from several sources ${ }^{40}$, admits that the Arabs were more tolerant towards the Christians of the East than the Byzantines, and thus he puts many red circles around the Syraic accounts that attribute violent acts to the Arab conquest. As Martinez notes, "They prove, at the very least, that not all Christians in the East welcomed the Muslims as liberators from the Byzantine yoke". ${ }^{41}$ I think this is one of the major determinant that must be taken into account to understand the ideologies which motivated the Syriac sources.

On the part of Arab sources, the early religious ideology of humanity and mercy that Arab sources attribute to the early Islamic conquests, especially towards the so-called "ahl al-kitāb", i.e. "People of the Book" 42 , makes it difficult to find examples of extreme violence perpetrated by Arab armies. The Arabs viewed the Byzantines, even before the beginning of these conquests, as ahl kitāb. The Qur'ān says at the beginning of Sürat al-Rüm: "The Rūm have been overcome (by the Persians) in the more adjacent part of the earth. And even after their being overcome, they will overcome ... and upon that day the believers

\footnotetext{
${ }^{37}$ Dionysius states that the Arabs peacefully treated the Mesopotamian populations who surrendered, as the case of the Edessenes and Harrānites who were granted a covenant. But "the arrogant Romans" did not accept these assurances, so about 300 of them were killed in Tella. Next the Arabs went to Dara, took it and killed every Roman in the city. They also took "Rhesaina, Mardīn and Amida by amnesty and covenant and oaths". The Secular History of Dionysius of Tel-Mahrēe', 163. May we keep these events in mind when trying to interpret the Syriac accounts of monks' execution on mountain of Mardīn.

38 'The Secular History of Dionysius of Tel-Mahrē', 157.

39 'The Secular History of Dionysius of Tel-Maḥrē', 157.

${ }^{40}$ See Palmer's discussion. 'The Secular History of Dionysius of Tel-Mahrē', 95-99. Es. 98.

${ }^{41}$ Martinez, Eastern Christian Apocalyptic, v.

42 "People of the Book", i.e. those possessing written scriptures, in the first place Jews and Christians and a mysterious people or sect called the Șābians.
} 
(Muslims) will exult." ${ }^{, 43}$. The Arab sources explain this verse as follows: "when the Persians defeated the Rüm, the infidels of Quraysh were glad because Persia was more aggressive against Islam and Muslims, while the Rüm, as Ahl kitāb, were more friendly". ${ }^{44}$

The jiha $\bar{d}$, which is believed to be the main religious-ideological motivation for Muslim conquests, ${ }^{45}$ was not seen by Muslims as a contradiction to how they felt about ahl al-kitāb, but that every Muslim must fulfill the sacred mission of spreading Islam. While accomplishing this mission they must avoid violent and brutal means. When Abū Bakr sent Islamic armies to Syria under the command of Yazīd ibn Abū Sufyān, he advised him: "You will find people who have dedicated themselves to God, keep them in peace. I advise you with ten: Do not betray or mutilate the bodies of the victims. Do not kill the old men, woman, children and animals. Do not burn palms, and do not destroy inhabited areas...". Likewise, Umar b. al-Khatțāb used to advise his armies: "Do not transgress; God does not love aggressors. ${ }^{46}$ Do not avoid fighting. Do not be exaggerate when beating, mutilating dead bodies, or killing old people, women, and children. But be eager to fight when it takes place." 47

Undoubtedly, the harsh nature of the battlefields does not allow us to expect full compliance with these tips. The book Futūh Bilād al-Shàm, attributed to al-Wāqidī (130-207/747-823), is the only Arab evidence for acts of violence, or even extreme violence, committed during the early Arab-Byzantine battles in Syria and Palestine. Al-Wāqidī, who provides comprehensive details of these battles, reflects their bloody nature, and records thousands of victims and captives on both sides. ${ }^{48}$ The noteworthy

${ }^{43}$ Ghālī, M. M., Towards Understanding the Ever-Glorious Qur'ān, Cairo: Dār anNashr Liljami‘āt, 2008, 405.

44 Al-Ṭabarī (Moḥmmad Abū al-Faḍl b. Garīr), Tafsīr, ed. A.M. Shākir, Beirut, 2000, $\mathrm{XX}, 73 \mathrm{f}$.

${ }^{45}$ There is a massive number of works deal with idea and notion of the jihād, see: M. Canard, "la guerre sainte dans le monde islamique et dans le monde chrétien", Revue africaine (1936), 605-623, repr. in idem, Byzance et les musulmans du proche orient, no. VIII; M. Watt, "Islamic Conceptions of the Holy War", in: T. Murphy (ed.), The Holy War, Ohio: Ohio University Press, 1976; M. Donner, "The Sources of Islamic Conceptions of War", in: J. Kelsay \& J. Johnson (eds.), Just War and Jihad: Historical and Theoretical Perspectives on War and Peace in Western and Islamic Traditions, London, 1991, 31-69; Idem, "Some Observations Concerning the Early Development of Jihad on the Arab-Byzantine Frontier", Studia Islamica 75 (1992), 531.

${ }^{46}$ Ghālī, Qur'ān, III:190, 29.

${ }^{47}$ Al-Ṭabarī, Tarīkh, II, 246.

${ }^{48} \mathrm{He}$ records that the numbers of the killed Byzantines are: 1200 against 120 Arabs in the battle of Tabūk; 50,000 in Ajnādīn; 5000 in Emesa; 40,000 in the battle of alTa'wīr; 105,000 in the battle of al-Yarmūk and 40,000 captives against 4000 Arabs. 
feature of al-Wāqidì's book is the contradiction that Arabs encountered many times, between the ideology of tolerance and the strategic necessity of the battlefields. For example, they had to execute the Byzantine women who took up arms against them. ${ }^{49}$ Also, they sometimes had to mistreat monks who collaborated with the Byzantines. ${ }^{50}$

Al-Wāqidī frequently makes a distinction between the true faithful Christians and those whom he calls "the worshipers of the Cross". He seems to get this distinction from a speech of Abu Bakr addressed to the Arab armies before their advance toward Syria. According to him, Abū Bakr said that: "You will pass along people in cells called Ruhbān, i.e. monks. They claim that they take the vow for God. So, let them in peace and do not destroy their cells. Also, you will find others belonged to Devil's party and worshipers of the Cross. You must put them to sword until they convert to Islam or pay al-jizyah". ${ }^{51}$ Undoubtedly, this speech mainly expresses one of the main components of the jihad, that is giving ahl dhema one of three choices: Islam, al-jizyah, or the sword.

In most cases, the Byzantines rejected the first two options and resorted to the option of war. During this war, they always carried the cross and prayed to him for victory. Therefore, al-Wāqidī usually refers to them as "worshipers of the cross" and "infidels" not as Christians. ${ }^{52}$

Al-Wāqidī (Muḥammad b.'Omar b. Wāqid), Futūḥ al-Shām, ed. Ṭ.A. Sa'd, Alexandria: Dār Ibn Khaldūn, n.d., I, 25, 90, 202, $282,292$.

49 The Arabs had to fight Byzantine warrior women near Damascus and killed some of them. Also, after the battle of al-Yarmūk, 'Omar b. al-Khațāb ordered to distinguish between the ordinary women and the warrior ones and killing the later. Al-Wāqidī, Futūh al-Shām, I, p115, 296

${ }^{50} \mathrm{Kha}$ iid b. al-Walīd said to a monk sympathetic with Byzantines "Unless the messenger of the God ordered us not to harm you, I will kill you with an evil manner". Also, $\mathrm{Sa}{ }^{\prime} \overline{\mathrm{i}} \mathrm{d}$ b. "Amer said to other monks: "Although our Prophet orders us not to harm a monk that confines himself in a cell, but I can not leave you so free to help the enemy", then he ordered to bind and arrest them. Al-Wāqidī, Futūh al-Shām, I, p139, 234.

${ }^{51}$ Al-Wāqidī, Futūh al-Shām, I, 23. He seems fabricate this formula. Other Arabic and Syrian sources mention another form of the speech. According to the Jacobite Patriarch Dionysius of Tel-Mahrē (818-845), Abū Bakr said: "Do not force the stylite from his high perch and do not harass the solitary. They have devoted themselves to the service of God. Wherever you are welcomed by a city or a people, make a solemn pact with them and give them reliable guarantees that they will be ruled according to their laws and according to the practices which obtained among them before our time. They will contract with you to pay in tribute whatever sum shall be settled between you, then they will be left alone in their confession and in their country. But as for those who do not welcome you, make war on them." "The Secular History of Dionysius of Tel-Mahrēe', 145.

52 Al-Wāqidī seems to present Arab-Byzantine war as a holy one on both sides. He refers to the Arabs as "carriers of the Qur'ān" and "the people of the Qur'ān" against the Byzantines who are "worshipers of the Cross", "the infidel worshipers of the Cross" and "the people of atheism who are believed in the Cross". According to him, 
As for the Syrians, while some of their cities surrendered peacefully and helped the Arab armies against the Byzantines, there were many cities that resisted the Arabs and chose war. However, the entire Syrian population was granted without distinction the freedom to choose between converting to Islam or paying the tax (al-jizyah) as dhimmis. Therefore, al-Wāqidī always considers them Nașarā, i.e. Christians, and People of the Book. ${ }^{53}$ This distinction may be a justification, adopted by al-Wāqidī, to explain some aspects of extreme violence he attributed to the Arabs during their wars against the Byzantines.

Al-Waqdi attributes to the Arabs their resorting often to the execution of Byzantine captives for refusing to convert to Islam. According to him, in 13/634, Khāid b. al-Walīd captured two Byzantine Patrikoi near Damascus and killed them for refusing to convert to Islam. ${ }^{54} \mathrm{He}$ also beheaded one of the patrikioi and carried his head to terrorize his captured brother, Paul Patrikois of Damascus, who was later executed for the same reason. ${ }^{55}$ On the eve of al-Yarmūk, when the Prophet Cousin, al-Zubaīr d. al-'Awwām, killed Nicetas, the Patrikios of 'Amān, he ordered the 4,000 heads of Byzantine soldiers to be transported and put on the tops of spears, and then he sent them with 1,000 captives to Damascus, where the commander in chief, 'Ubayda b. al-Jarrāh, ordered to execute them. ${ }^{56}$ Also, after the capture of Aleppo, Khālid b. al-Walīd executed 300 Byzantine captives in its castle for their rejection of Islam. ${ }^{57}$

Also, al-Wāqidi attributed to the Arabs that they often put the heads of the Byzantine Patrikoi and soldiers on the tip of their spears to intimidate the Byzantines or to celebrate victory after battles. He presents a heroic figure named Dirrār b. al-Azwar who terrified the Byzantines by his repeatedly killing the Patrikoi and placing their heads on the tip of his spear. ${ }^{58}$ In the battle of Ajnādīn, the Patrikios Werdān begged Khāid $b$. al-Walīd to kill him with his own hand, not at the hands of Dirrār, saying: "In the name of Christ kill me with your own hands and do not let this devil kill me". Khāid did not response to him, and when Dirrār killed

Byzantine armies always carry the Cross to help them and achieve victory. They usually full of priests and monks who repeated verses from the Bible and blessed soldiers. Al-Wāqidī, Futūh al-Shām, I, 59, 60, 61-62, 63, 65, 77,90, 93, 96, 97, 98-99, 136, 204, 205-206, 221, 225, 234, 246, 256, 274, 301, 302.

${ }^{53}$ Al-Wāqidī ascribes to the Arab General Răfi' al-Ṭā'̄ a speech that he addressed to the Christians of Damascus before its capture, he says: "O Ahl al-kitāb, attack with us the infidel worshipers of the Cross' Al-Wāqidī, Futūh al-Shām, I, 63.

${ }^{54}$ Al-Wāqid̄̄, Futūh al-Shām, I, 58.

${ }^{55}$ Al-Wāqidī, Futūh al-Shām, I, 76.

${ }^{56}$ Al-Wāqidī, Futūḥ al-Shām, I, 235.

${ }^{57}$ Al-Wāqidī, Futūh al-Shām, I, 338.

${ }^{58}$ Al-Wāqidī, Futūḥ al-Shām, I, 76, 89. 
him, "the swords of al-mujāhidin gathered and torn him to sherds, then they carried his head to terrify the hearts of the Byzantines". ${ }^{5}$

Likewise, 'Abd al-Rahman b. Abū Bakr killed the Patrikios Tomas near Damascus, then sat on his chest and cut off his head and placed it on the tip of his spear. ${ }^{60}$ After capturing Aleppo, the Arabs carried the heads of its Patrikios and 700 Byzantine soldiers on the top of spears to Damascus. ${ }^{61}$

In contrast to Eastern Christian writers, and somewhat Byzantine, who were motivated by ideological impulses, Al-Wāqidī seems to believe that violence, or extreme violence, is a strategic necessity required by wars against infidels. He frequently considered it an act of heroism and courage that was necessary to terrify them. ${ }^{62}$ Nevertheless, he remains unique both in his comprehensive account of the ArabByzantine wars during the conquest of Syria and in his notions of the ideologies that guided them. It seems that other later Arabic sources, which sometimes quote him, completely avoid his perceptions, and do not comment on them or mention the extreme violence that he attributed to the Arab armies, but only record the large numbers of the Byzantine dead and captives. ${ }^{63}$ However, there are still very few signs of violence, but this time on both sides. ${ }^{64}$ According to them, after Ja'far b. Abī Ṭālib was killed in the battle of Mu'ta, the Arabs found more than 80 stab

${ }^{59}$ Al-Wāqidī, Futūḥ al-Shām, I, 89. Cf. Muhammad, "Had the Arabs Military Skills," 75.

${ }^{60}$ Al-Wāqid̄̄, Futūḥ al-Shām, I, 116.

${ }^{61}$ Al-Wāqidī, Futūḥ al-Shām, I, 338.

62 According to him, Byzantines many times described the Arabs as "bloodthirsty", and he does not put any comment but seems accepting this as a source of their cowardliness. Al-Wāqidī, Futūh al-Shām, I, 85, 104.

${ }^{63}$ Al-Balādhurī (d. c. 279/892) records that Khāid b. al-Walīd attacked the Christians of Ghassān in the Easter Day 13, captured and executed many. According to him, the Arab armies killed 10,000 Byzantine soldiers with this Patrikios in the battle of Fahl 13, and 70,000 in the battle of al-Yarmūk. Al-Balādhurī (Aḥmad b. Yahyā b. Jāber), Futūh al-Buldān, ed. ed. T. A. Sa'd, Alexandria: Dār Ibn Khaldūn, n.d., 140, 159 (224-310) and Ibn al-Athīr (d. 630) record 80,000 in Faḥl 14, and 80,000 in Caesarea 19. They refer to the outcome of Marg al-Rüm battle by saying that "The Marg was full of their killed to the extent that the land became rotten". Al-Ṭabarī, Tarìkh, III, 443, 604, 598; Ibn al-Athīr, Al-Kāmil, II, 280,344, 338.

${ }^{64}$ Also, references to Muslims as "believers" and to Byzantines as "infidels" still found in these sources. In the battle of Mu'ta, Ga'far b. Abī Țālib took the banner of the Prophet to fight by it, saying "welcome Paradise with its beauty and cold drink. Pain of the Rüm, who are infidels and of low race, become imminent". Also, in the battle of al-Yarmūk, Abū Sufyān stopped at the head of Arab armies saying, "You are the defenders of Arabs and protectors of Islam, while the others are the defenders of the Rüm and protectors of polytheism". Later, when the Byzantines defeated Arabs near Tayna 88 H., al-Walīd b. 'Abd al-Malik cried among his soldiers saying, "O owners of the Qur'ān, come all”, then they gained victory and captured the city. Ibn al-Athīr, alKāmil, II, 113; Al-Ṭabarī, Tarīkh, III, 397, VI, 434. 
wounds to his body. ${ }^{65}$ In the battle of Ajnādīn, when the Byzantine Qubuqlār, i.e. koubikoularios, realized that his end was imminent and covered his head with a piece of cloth, the Arabs killed him and cut him off. ${ }^{66}$

In sum, a reader of Eastern Christian texts dealing with the early Arab-Byzantine wars can note clear ideological motives. They often attribute to the Arabs extreme violence directed not against their warrior enemies but against civilians and sometimes monks. The accusation of Arabs of extreme violence is increasing in the texts of writers with a religious background. Some scholars have relied on these texts as an evidence for the violence of the Arab conquests without taking into account the influence of the religious background on those writers who saw Islam as a threat to Christianity, and then on their influence and positions as clerics. Some of them expressed their strong dissatisfaction with the conversion of the people of their churches to Islam and considered this a divine punishment for the moral sins of Christians. Thus, it seems that some of them exaggerated the bloody and brutal punishment in preparation for forgiveness and the final victory of true Christians over Muslims. This approach may be supported by a comparison of what they wrote with other non-fanatic clerics who were more inclined to the pacifism of the Arab conquests.

On the other hand, the position of the Byzantine writers seems closer to the Arab position. They do not limit the violence to the Arabs only, but refer to the violence of the two opponents, the Arabs and the Byzantines. At times, they justified the violence of Arab fighters against rebels or enemy collaborators. This is largely in agreement with Arabic sources, and although related Arabic accounts are scarce, what is available of them indicate a common violence between the two rivals. Al-Wāqidī is a unique source in his reference to incidents of mutual violence. However, although he mentioned a number of violent incidents perpetrated by the Arab side, he often justified this by the necessity of the strategy required by the wars against the unbelievers He frequently considered it an act of heroism and courage that was necessary to terrify them.

\footnotetext{
${ }^{65}$ Ibn al-Athīr, Al-Kāmil, II, 114.

${ }^{66}$ Al-Ṭabarī, Tarīkh, III, 418.
} 